\title{
Nutrient composition and functional properties: suitability of flour of sweet potatoes (Ipomea batatas) for incorporation into food production
}

\author{
G. R. Nipuni Nayanathara WAIDYARATHNA and Sagarika EKANAYAKE*
}

Department of Biochemistry, Faculty of Medical Sciences, University of Sri Jayewardenepura, Sri Lanka.

*Corresponding author; E-mail: sagarikae@hotmail.com/sagarikae@sjp.ac.lk; Tel. (+94)0716875891.

\begin{abstract}
Received: 13-09-2020
Accepted: 06-03-2021

Published: 30-06-2021

ABSTRACT

Sweet potatoes are effortlessly grown and high yielding food crop. However, these are considered as underutilized produce with limited incorporation into food industry. Hence the objectives of this study were to determine the nutrient composition and functional properties of twelve (12) sweet potato varieties available in Sri Lanka to study the potential to be incorporated into food production. The varieties analysed were Ama, Dhawala, Wariyapola White, Wariyapola Red, Shanthi, Hordi Malee, CARI 09, CARI 273, Ranabima, Gannoruwa White, Chithra and Makandura Purple. Determination of moisture, ash, crude protein, crude fat, dietary fiber (soluble/insoluble), carbohydrates and functional properties were by standard methods. Ash, crude fat and crude protein contents comprised less than 7\% (dry matter; DM) with total carbohydrate content varying between $49-80 \% \mathrm{DM}$ in studied sweet potatoes. Total dietary fiber comprises approximately $8.5 \%$ (DM) with the highest proportion being insoluble dietary fiber. Functional properties resulted a swelling capacity of 15-27 mL with high oil absorption capacity (120-220\%), emulsion activity (42-48\%) and stability (above $35 \%$ ), and bulking density $(0.62-0.95 \mathrm{~g} / \mathrm{cc})$ with least gelation concentration of $18-30 \%$. The results prove the ability of the studied sweet potato flours to be incorporated in composite flour mixtures and novel food products.
\end{abstract}

(C) 2021 International Formulae Group. All rights reserved.

Keywords: Dietary fiber, emulsion activity, least gelation concentration, oil absorption capacity, swelling capacity.

\section{INTRODUCTION}

Sweet potato (Ipomoea batatas L) which originated from Central America is a dicotyledonous plant that belongs to the family Convolvulaceae (Shekhar et al., 2015). Sweet potato is the world's seventh most important food crop (Mussoline and Wilkie, 2017) and cultivated in tropical, subtropical and temperate regions ( Shekhar et al., 2015; Doussoh et al., 2016) in more than 100 countries in South East Asia, Africa, Oceania, and Latin America regions and China. The world's leading sweet potato producer with more than $75 \%$ of the world's production is China (FAO, 2016).

Sweet potato is effortlessly grown, high yielding, tolerate many farming conditions with strong resistance capabilities for different environmental, soil, and temperature conditions and pesticides are rarely needed. Therefore, sweet potatoes are considered as a typical food security crop for 
deprived populations as this can be harvested little by little over a long period of time (Chandrasekara and Kumar, 2016).

Since many decades, sweet potato is considered as a low cost energy source for Sri Lankans as well. Tuberous roots of sweet potatoes are large, starchy, sweet-tasting and consumed as a root vegetable. The color of tuberous flesh ranged from white, red, pink, violet, yellow, orange and purple. All varieties are rich sources of phenolic compounds and antioxidants with purple sweet potato variety (Tang et al., 2015) dominating. The tubers contain flavonoids (Wang et al., 2018) and carotenoids (Djinet et al., 2014) which contribute to their antioxidant potential. Proximate composition data on sweet potatoes prove that these are a good source of starch with low crude protein, crude fat, mineral and crude fibers (Oluwalana et al., 2012; Senanayake et al., 2013a).

Sri Lanka has more than 20 varieties of sweet potatoes. Although sweet potato is one of the common, easily accessible and low cost tuber crop, the use of sweet potatoes for the consumption and industrial use is not up to its full potential due to lack of adequate nutritional and functional information which are important in incorporation of sweet potato flour in food industry. Thus the aim of the present study was to make available data on nutrient composition and selected functional properties of twelve (12) traditional and newly developed sweet potato varieties in Sri Lanka as only few related research findings are available.

\section{MATERIALS AND METHODS Sample collection}

Twelve (12) sweet potato varieties selected for the study were Ama, Dhawala, Wariyapola White $(W W)$, Wariyapola Red (WR), Shanthi, Hordi Malee (HM), CARI 09, CARI 273, Ranabima, Gannoruwa White (GW), Chithra and Makandura Purple (MP) (Figure 1). Sweet potato samples were collected from Plant Genetic Resource Center Gannoruwa, Sri Lanka. The newly introduced variety Makandura Purple was obtained from
Makandura Agricultural Research Center, Makandura, Sri Lanka.

\section{Sample preparation}

Sweet potato samples were washed, hand peeled (minimal removal of peel) and trimmed to remove defective parts. Tubers were grated into thin chips and dried $\left(55^{\circ} \mathrm{C}\right)$ for 3-4 days. Dried samples were milled (IKA ( $\mathrm{A} 11$ basic, New Zealand), sieved and stored $\left(-20{ }^{\circ} \mathrm{C}\right)$ in tightly closed containers until subjected to the following analyses.

\section{Proximate composition of sweet potato flour}

Sweet potato flour samples $(0.5000 \mathrm{~g})$ were accurately weighed (Sartorius, Max 110 $\mathrm{g}$, Germany) in to pre weighed and labeled porcelain crucibles. The samples were oven dried using a hot air oven (Memmert, Germany) at $105^{\circ} \mathrm{C}$ until constant weight. The weight loss was considered as the moisture content (AOAC, 1984).

Accurately measured sweet potato flour samples $(0.5000 \mathrm{~g})$ were transferred into porcelain crucibles and ignited in the muffle furnace (Hobersal, Barcelona, Spain) at 550 ${ }^{\circ} \mathrm{C}$ for 5-6 hours. Sample residues were weighed (AOAC, 2000) as ash content.

Total carbohydrate content of tuber samples was determined using enzymatic assay with Megazyme total starch assay procedure; (amyloglucosidase/ $\alpha$-amylase method; K-TSTA-50A/K-TSTA-100A 06/17; Megazyme, Ireland) without washing off simple sugars present in the samples. Total carbohydrate was also determined by phenol sulfuric method (Dubois et al., 1956).

Crude fat content was determined using the method described by Croon and Guchs (1980) with modification. Samples were accurately measured and transferred in to Majonnier flasks. Samples were moistened with ethanol $(95 \%, 2 \mathrm{~mL})$ and digested with hydrochloric acid (7.7 M, $10 \mathrm{~mL})$ and incubated $\left(75{ }^{\circ} \mathrm{C}, 1\right.$ hour). Ethanol $(95 \%, 10$ $\mathrm{mL}$ ) was added to the tubes after reaching the room temperature. Fat separation was done thrice by mixing and shaking with peroxide 
free petroleum ether: diethyl ether (using 25 $\mathrm{mL}, 1: 1$ one time and $30 \mathrm{~mL}, 1: 1$ twice). The upper layers in each Majonnier flask were separately transferred to prior weighed clean dry conical flasks and allowed the solvent to evaporate. Final dried weights of conical flasks were measured. Crude fat content of each sweet potato variety was calculated using the weight difference of each conical flask and the initial sample weight.

Micro Kjeldhal apparatus (Paranas Wagner still) was used for the crude protein analysis (AOAC, 1984). A conversion factor of 6.25 was used to determine the protein content from Kjeldhal nitrogen.

Sigma Aldrich total dietary fibre assay kit (TDF 100A-1KT, SIGMA ALDRICH, USA) was used for the analysis. Digested sample mixture was filtered through cleaned and dried syntax crucibles (Pyrex, England, No: 4). Insoluble dietary fibre content was determined according to the procedure given in the assay kit and the filtrate of each sample used for quantification of soluble fibre by diluting with 4 volumes of $95 \%$ ethanol. The solutions were kept overnight at room temperature for soluble dietary fiber to precipitate. Filtration process was followed as for insoluble fiber determination. Collected fiber fractions were corrected for trapped protein and mineral content by Kjeldhal assay and ashing.

\section{Functional properties of sweet potato flour}

Determination of swelling capacity was done using the method described by Okaka and Potter (1977). Graduated cylinder $(100 \mathrm{~mL})$ was filled with raw flour up to 10 $\mathrm{mL}$ mark. Distilled water was added up to 50 $\mathrm{mL}$ mark. The top of the graduated cylinder was tightly covered and mixed by inverting the cylinder. The suspension was inverted again after 2 minutes and left to stand for a further 8 minutes. The volume occupied by the flour was taken after the $8^{\text {th }}$ minutes.

For the determination of oil absorption capacity, sweet potato flour sample (1.000 g) was mixed with $10 \mathrm{~mL}$ soybean oil (Sp.
Gravity: 0.9092) and allowed to stand at ambient temperature $\left(30 \pm 2{ }^{\circ} \mathrm{C}\right)$ for 30 minutes. Mixture was centrifuged for $30 \mathrm{~min}$ at $4000 \mathrm{rpm}$. Oil absorption was expressed as percent oil bound per gram flour (Sosulski et al., 1976).

In emulsion activity and stability determination, flour sample $(1.000 \mathrm{~g})$ of each variety was mixed with distilled water (10 $\mathrm{mL})$ and soybean oil $(10 \mathrm{~mL})$ in a calibrated centrifuge tube. The emulsion was centrifuged at $4000 \mathrm{rpm}$ for $5 \mathrm{~min}$. The ratio of the height of emulsion layer to the total height of the mixture was calculated as emulsion activity in percentage. For the estimation of emulsion stability, the emulsion contained in calibrated centrifuged tube was heated at $80{ }^{\circ} \mathrm{C}$ for 30 min in a water bath, cooled for 15 minutes under running tap water and centrifuging at $4000 \mathrm{rpm}$ for $15 \mathrm{~min}$. The percentage emulsion stability was calculated as the ratio of the height of emulsified layer to the total height of the mixture (Yasumatsu et al., 1972).

Foam capacity and foam stability was determined by adding flour samples $(0.5000$ g) to distilled water $(25 \mathrm{~mL})$ at $30 \pm 2{ }^{\circ} \mathrm{C}$ in a graduated centrifuge tube. The suspension was mixed and shaken for $5 \mathrm{~min}$ to make foam. Volume of the foam at 30s after whipping was expressed as foam capacity as a percentage of initial foam volume. Foam stability was determined by measuring the foam volume an hour after whipping and expressed as percentage of initial foam volume (Chandra et al., 2015).

The flour dispersions of $2,4,6,8,10$, $12,14,16,18,20,22$, and $30 \%(w / v)$ prepared in $5 \mathrm{~mL}$ distilled water was heated at $90{ }^{\circ} \mathrm{C}$ for $1 \mathrm{~h}$ in a water bath. The contents were cooled under tap water and kept for $2 \mathrm{~h}$ at $10 \pm 2{ }^{\circ} \mathrm{C}$. The least gelation concentration was taken as the concentration when the sample from inverted tube did not slip (Chandra et al., 2015).

Flour sample $(100.00 \mathrm{~g})$ from each sample was measured in a measuring cylinder $(250 \mathrm{~mL})$. The measuring cylinder was tapped 
on a wooden plank until no visible decrease in volume noticed. The apparent (bulk) density was calculated based on the weight and volume (Jones et al., 2000).

\section{Statistical analysis}

Data are presented as mean $\pm \mathrm{SD}$. Significances were calculated at $95 \%$ confidence interval. The data were analyzed using the statistical software (SPSS) and Microsoft Office Excel 2010.

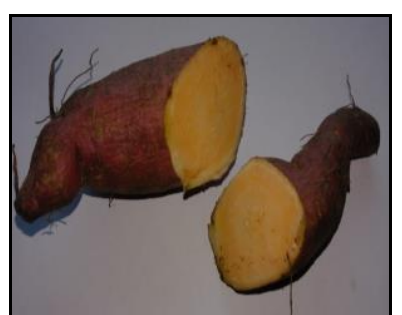

(a)

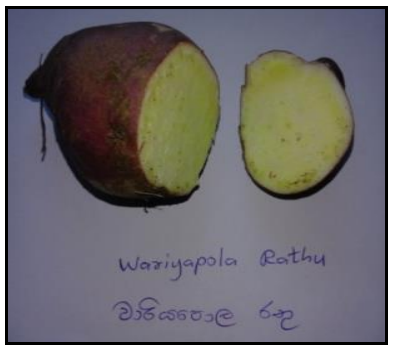

(d)

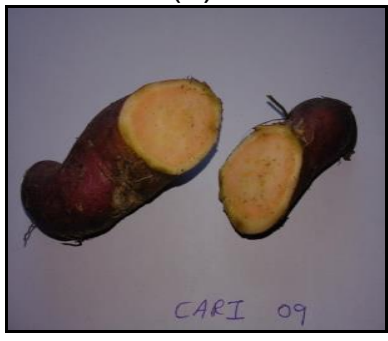

(g)

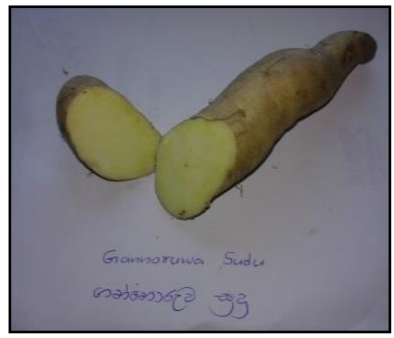

(j)

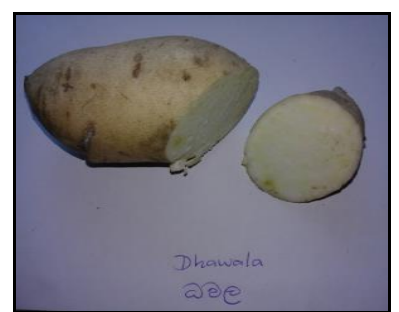

(b)

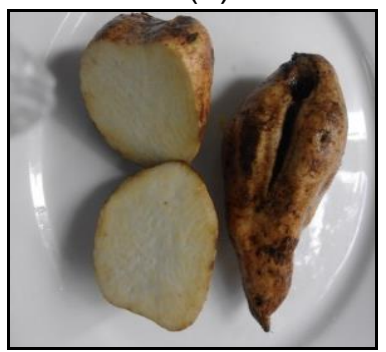

(e)

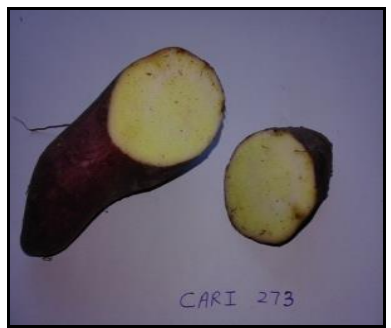

(h)

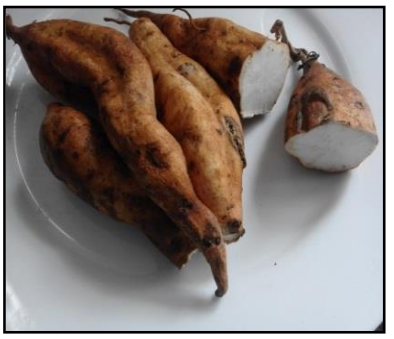

(k)

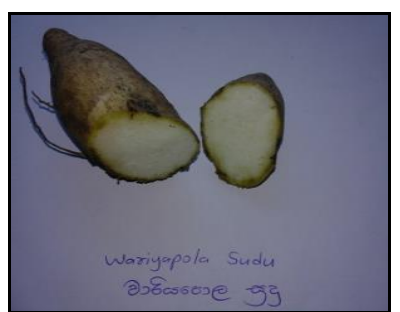

(c)

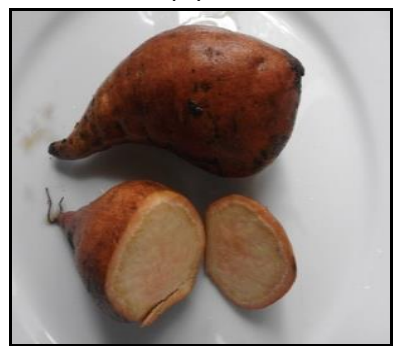

(f)

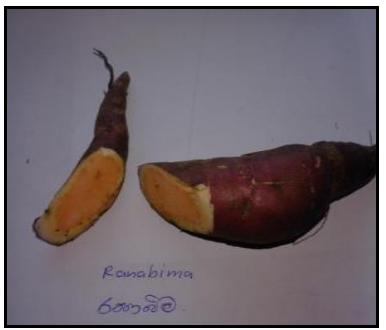

(i)

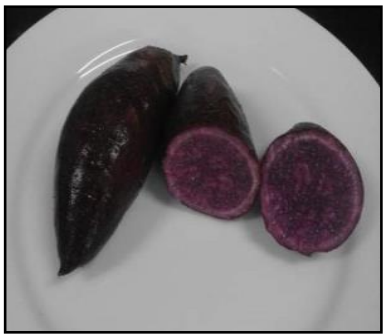

(l)

Figure 1: Sweet potato samples used in the study.

(a) Ama; (b) Dhawala; (c) Wariyapola White; (d) Wariyapola Red; (e) Shanthi; (f) Hordi Malee; (g) CARI 09; (h) CARI 273; (i) Ranabima; (j) Gannoruwa White; (k) Chithra; (l) Makandura Purple. 


\section{RESULTS}

The moisture, ash, crude protein and fat contents of sweet potatoes are presented in Table 1. Moisture content of sweet potato tuber flour of the tested varieties varied between 2-8\%. Gannoruwa White had the highest moisture content among the tested varieties while $H M$ variety was found with significantly low $(\mathrm{P}<0.05)$ moisture content.

Ash content which reflects constituent minerals ranged from $2-6 \%$ on dry weight basis in sweet potato flour. Gannoruwa White and Chithra varieties had significantly high ( $\mathrm{P}$ $\leq 0.05$ ) ash contents while Ama, Shanthi and $M P$ had lower $(\mathrm{P} \leq 0.05)$ ash contents.

The crude protein content of flour was above $3 \%$ and less than $5 \%$ except in $M P$ variety $(6.6 \%)$ which had the highest $(\mathrm{P} \leq$ $0.05)$ crude protein content. Crude fat content of flour ranged between 3-6\% while $W W$, WR, CARI 09, CARI 273 and $G W$ had significantly high $(\mathrm{P} \leq 0.05)$ fat contents compared to other varieties.

Table 2 shows the total carbohydrate content determined using enzymatic assay procedure (total carbohydrates, including resistant starch and total), total carbohydrate by phenol sulfuric method and total dietary fiber content including insoluble and soluble dietary fibers.

Carbohydrate is the major nutrient present in all the tested sweet potato varieties according to both the enzymatic digestion method and phenol sulfuric method (49-74\%). The highest $(\mathrm{P} \leq 0.05)$ carbohydrates were found in $M P$ while the lowest $(\mathrm{P} \leq 0.05)$ were found in Chithra and Ranabima varieties based on the enzymatic method and phenol sulfuric method respectively.

Total dietary fiber content of flour ranged from $8.7 \%-17.7 \%$ on $\mathrm{DM}$, with significantly high $(\mathrm{P} \leq 0.05)$ total dietary fiber content in Ranabima and significantly low ( $\mathrm{P}$ $\leq 0.05$ ) content in Shanthi. Insoluble dietary fiber content provided higher contribution to the total dietary fiber content which ranged from $6-13.5 \%$ while soluble dietary fiber content of sweet potato varieties ranged from 2-8\%. Makandura Purple variety had significantly high $(\mathrm{P} \leq 0.05)$ insoluble dietary fiber while $W R$ and Shanthi had significantly low $(\mathrm{P} \leq 0.05)$ contents. Varieties Ranabima and $G W$ had significantly high $(\mathrm{P} \leq 0.05)$ soluble fiber followed by HM and CARI 273.

Functional properties of sweet potato flour are presented in Table 3. Swelling capacity of the studied varieties ranged between 15-27 mL. Significantly high $(\mathrm{P} \leq$ 0.05) swelling capacities were found in $C A R I$ 09, HM, CARI 273 and $G W$ with lowest (P $\leq$ $0.05)$ in Shanthi. Oil absorption capacity of the tested sweet potato flour varied between 120-220\%. Wariyapola White, Shanthi, GW and Chithra had significantly high $(\mathrm{P} \leq 0.05)$ oil absorption capacities with significantly low $(\mathrm{P} \leq 0.05)$ values in Ama and MP.

Emulsion activity and emulsion stability of sweet potato flour ranged between $42 \%-48 \%$ and $38 \%-42 \%$ respectively. The highest $(\mathrm{P} \leq 0.05)$ emulsion activity and stability were found in Ranabima and CARI 273 respectively.

The foam capacity and foam stability of all the sweet potato flour were insignificant. The least gelation concentration of the sweet potato flour in present study varied between 18-30\%. The lowest least gelation concentration was observed in Ranabima variety.

Bulking density of the sweet potato varieties varied between $0.62-0.95 \mathrm{~g} / \mathrm{cc}$ with the highest bulking density in $M P$ variety followed by Dhawala. No correlation between moisture and bulk density in raw sweet potato flour with same particle size was observed despite the variation in moisture (2-8\%). The variation in moisture may not be significant enough for causing a difference in bulk 
density. A strong positive correlation between total carbohydrates with bulking density $\left(\mathrm{r}^{2}=\right.$ 0.80 ) was observed. Bulking density showed weak positive correlations with the crude protein content $\left(r^{2}=0.15\right)$ and IDF $\left(r^{2}=0.15\right)$, while a weak negative correlation with the crude fat content $\left(\mathrm{r}^{2}=0.15\right)$. Carbohydrate contents showed a negative correlation with oil absorption capacity $\left(\mathrm{r}^{2}=0.50\right)$. Swelling capacity showed a positive correlation with SDF $\left(\mathrm{r}^{2}=0.35\right)$ as such $G W, H M$ and $C A R I$ 273 varieties.

Table 1: Moisture, ash, crude protein and fat contents of sweet potato flour on dry weight ( $\mathrm{g} / 100 \mathrm{~g})$ basis.

\begin{tabular}{lllll}
\hline Sweet potato varieties & Moisture & Ash\% & Crude protein \% & Crude fat \% \\
\hline Ama & $5.2 \pm 0.4^{\mathrm{a}}$ & $2.6 \pm 0.1^{\mathrm{a}}$ & $3.2 \pm 0.4^{\mathrm{a}}$ & $3.1 \pm 0.5^{\mathrm{a}}$ \\
Dhawala & $4.1 \pm 0.1^{\mathrm{b}}$ & $3.7 \pm 0.3^{\mathrm{b}}$ & $3.2 \pm 0.1^{\mathrm{a}}$ & $4.2 \pm 0.5^{\mathrm{a}, \mathrm{b}, \mathrm{d}}$ \\
WW & $6.8 \pm 0.3^{\mathrm{d}}$ & $4.0 \pm 0.1^{\mathrm{b}}$ & $4.9 \pm 0.3^{\mathrm{b}}$ & $6.2 \pm 0.4^{\mathrm{c}}$ \\
WR & $6.0 \pm 0.1^{\mathrm{c}}$ & $4.0 \pm 0.1^{\mathrm{b}}$ & $3.5 \pm 0.4^{\mathrm{a}}$ & $5.6 \pm 0.5^{\mathrm{c}}$ \\
Shanthi & $4.2 \pm 0.3^{\mathrm{b}, \mathrm{e}}$ & $3.0 \pm 0.3^{\mathrm{a}}$ & $4.0 \pm 0.1^{\mathrm{c}}$ & $4.0 \pm 0.4^{\mathrm{b}, \mathrm{d}}$ \\
HM & $2.2 \pm 0.1^{\mathrm{f}}$ & $4.1 \pm 0.1^{\mathrm{b}}$ & $3.7 \pm 0.1^{\mathrm{a}, \mathrm{c}}$ & $3.6 \pm 0.3^{\mathrm{a}}$ \\
CARI 09 & $6.7 \pm 0.1^{\mathrm{d}}$ & $4.0 \pm 0.4^{\mathrm{b}}$ & $3.5 \pm 0.1^{\mathrm{a}}$ & $5.4 \pm 0.4^{\mathrm{c}, \mathrm{d}}$ \\
CARI 273 & $4.6 \pm 0.2^{\mathrm{e}}$ & $4.2 \pm 0.3^{\mathrm{b}}$ & $3.2 \pm 0.1^{\mathrm{a}}$ & $5.9 \pm 0.5^{\mathrm{c}}$ \\
Ranabima & $5.9 \pm 0.2^{\mathrm{c}}$ & $4.2 \pm 0.3^{\mathrm{b}}$ & $3.4 \pm 0.1^{\mathrm{a}, \mathrm{c}}$ & $5.0 \pm 0.5^{\mathrm{d}}$ \\
GW & $8.2 \pm 0.1^{\mathrm{g}}$ & $5.6 \pm 0.1^{\mathrm{c}}$ & $4.8 \pm 0.1^{\mathrm{b}}$ & $5.5 \pm 0.5^{\mathrm{c}, \mathrm{d}}$ \\
Chithra & $4.5 \pm 0.2^{\mathrm{b}, \mathrm{e}}$ & $5.0 \pm 0.1^{\mathrm{c}}$ & $4.5 \pm 0.1^{\mathrm{b}}$ & $3.8 \pm 0.2^{\mathrm{a}}$ \\
MP & $5.2 \pm 0.1^{\mathrm{a}}$ & $3.3 \pm 0.1^{\mathrm{a}, \mathrm{b}}$ & $6.6 \pm 0.1^{\mathrm{d}}$ & $3.7 \pm 0.2^{\mathrm{a}}$ \\
\hline
\end{tabular}

Data presented as mean $\pm \mathrm{SD} ; \mathrm{n}=6$; In each column, different superscripts indicate varietal significant differences at $\mathrm{P} \leq 0.05$.

Table 2: Carbohydrate and dietary fiber content on dry weight (g/100g basis).

\begin{tabular}{|c|c|c|c|c|c|}
\hline \multirow{2}{*}{$\begin{array}{c}\text { Sweet potato } \\
\text { varieties }\end{array}$} & \multicolumn{2}{|c|}{ Total carbohydrate content } & \multicolumn{2}{|c|}{ Dietary Fiber (DF) } & \multirow[t]{2}{*}{ Total DF } \\
\hline & $\begin{array}{c}\text { Enzymatic } \\
\text { assay }\end{array}$ & $\begin{array}{l}\text { Phenol sulfuric } \\
\text { method }\end{array}$ & Insoluble & Soluble & \\
\hline Ama & $67.8 \pm 0.7^{\mathrm{a}}$ & $69.5 \pm 0.3^{\mathrm{a}}$ & $7.1 \pm 0.1^{\mathrm{a}}$ & $3.9 \pm 0.1^{\mathrm{a}}$ & $11.0 \pm 0.1^{\mathrm{b}}$ \\
\hline Dhawala & $66.5 \pm 0.4^{\mathrm{a}}$ & $71.8 \pm 0.9^{\mathrm{a}}$ & $7.3 \pm 0.1^{\mathrm{a}}$ & $2.8 \pm 0.1^{\mathrm{a}}$ & $10.1 \pm 0.1^{\mathrm{a}}$ \\
\hline$W W$ & $59.1 \pm 0.4^{\mathrm{b}}$ & $65.9 \pm 0.7^{b}$ & $8.8 \pm 0.1^{\mathrm{c}}$ & $3.7 \pm 0.1^{\mathrm{a}}$ & $12.5 \pm 0.1^{\mathrm{c}}$ \\
\hline$W R$ & $56.4 \pm 0.9^{\mathrm{b}, \mathrm{c}}$ & $65.7 \pm 0.9^{b}$ & $6.7 \pm 0.1^{\mathrm{b}}$ & $4.4 \pm 0.1^{\mathrm{a}}$ & $11.1 \pm 0.1^{\mathrm{b}}$ \\
\hline Shanthi & $53.7 \pm 0.2^{\mathrm{c}}$ & $70.1 \pm 0.8^{\mathrm{a}}$ & $6.4 \pm 0.1^{\mathrm{b}}$ & $2.3 \pm 0.1^{\mathrm{a}}$ & $8.7 \pm 0.1^{\mathrm{d}}$ \\
\hline$H M$ & $64.0 \pm 0.2^{\mathrm{a}}$ & $68.1 \pm 0.8^{\mathrm{a}}$ & $9.1 \pm 0.1^{\mathrm{d}}$ & $6.6 \pm 0.1^{\mathrm{b}}$ & $15.7 \pm 0.1^{\mathrm{e}}$ \\
\hline CARI 09 & $59.3 \pm 0.2^{\mathrm{b}}$ & $69.3 \pm 0.8^{\mathrm{a}}$ & $7.4 \pm 0.1^{\mathrm{a}}$ & $3.0 \pm 0.1^{\mathrm{a}}$ & $10.4 \pm 0.1^{\mathrm{a}}$ \\
\hline CARI 273 & $54.5 \pm 0.2^{\mathrm{b}} \mathrm{c}$ & $69.1 \pm 0.7^{\mathrm{a}}$ & $8.2 \pm 0.1^{\mathrm{c}}$ & $6.2 \pm 0.1^{\mathrm{b}}$ & $14.4 \pm 0.1^{\mathrm{f}}$ \\
\hline Ranabima & $54.2 \pm 0.3^{\mathrm{b}, \mathrm{c}}$ & $64.3 \pm 0.8^{\mathrm{b}}$ & $9.5 \pm 0.1^{\mathrm{d}}$ & $8.2 \pm 0.1^{\mathrm{c}}$ & $17.7 \pm 0.1^{\mathrm{g}}$ \\
\hline $\boldsymbol{G W}$ & $60.4 \pm 0.2^{\mathrm{b}}$ & $67.5 \pm 0.6^{\mathrm{a}}$ & $8.7 \pm 0.1^{\mathrm{c}}$ & $7.9 \pm 0.1^{\mathrm{c}}$ & $16.6 \pm 0.1^{\mathrm{h}}$ \\
\hline Chithra & $49.3 \pm 0.3^{\mathrm{d}}$ & $65.1 \pm 0.8^{\mathrm{b}}$ & $11.8 \pm 0.1^{\mathrm{f}}$ & $2.1 \pm 0.1^{\mathrm{a}}$ & $13.9 \pm 0.1^{\mathrm{f}}$ \\
\hline$M P$ & $73.5 \pm 0.4^{\mathrm{f}}$ & $77.1 \pm 0.8^{\mathrm{d}}$ & $13.4 \pm 0.1^{\mathrm{g}}$ & $3.1 \pm 0.1^{\mathrm{a}}$ & $16.5 \pm 0.1^{\mathrm{h}}$ \\
\hline
\end{tabular}

Data presented as mean $\pm \mathrm{SD} ; \mathrm{n}=6$; In each column, different superscripts indicate varietal significant differences at $\mathrm{P} \leq 0.05$. 
Table 3: Functional properties of sweet potato flour.

\begin{tabular}{|c|c|c|c|c|c|c|}
\hline $\begin{array}{l}\text { Sweet } \\
\text { potato } \\
\text { varieties }\end{array}$ & $\begin{array}{l}\text { Swelling } \\
\text { capacity } \\
(\mathbf{m L})\end{array}$ & $\begin{array}{c}\text { Oil } \\
\text { absorption } \\
\text { capacity }(\%)\end{array}$ & $\begin{array}{c}\text { Emulsion } \\
\text { activity } \\
(\%)\end{array}$ & $\begin{array}{c}\text { Emulsion } \\
\text { stability }(\%)\end{array}$ & $\begin{array}{c}\text { Least } \\
\text { gelation } \\
\text { concentration } \\
(\%)\end{array}$ & $\begin{array}{c}\text { Bulking } \\
\text { density } \\
\text { (g/cc) }\end{array}$ \\
\hline Ama & $20.0 \pm 0.1^{\mathrm{a}}$ & $120 \pm 0.1^{\mathrm{a}}$ & $44.1 \pm 0.1^{\mathrm{a}}$ & $40.2 \pm 0.1^{\mathrm{a}}$ & $30.0^{\mathrm{a}}$ & $0.82 \pm 0.1^{\mathrm{a}}$ \\
\hline Dhawala & $20.0 \pm 0.1^{\mathrm{a}}$ & $160 \pm 0.1^{\mathrm{b}}$ & $42.2 \pm 0.1^{\mathrm{b}}$ & $38.2 \pm 0.1^{\mathrm{b}}$ & $30.0^{\mathrm{a}}$ & $0.89 \pm 0.1^{\mathrm{a}}$ \\
\hline$W W$ & $20.0 \pm 0.1^{\mathrm{a}}$ & $220 \pm 0.1^{c}$ & $45.2 \pm 0.1^{\mathrm{a}}$ & $40.4 \pm 0.1^{\mathrm{a}}$ & $30.0^{\mathrm{a}}$ & $0.72 \pm 0.1^{\mathrm{c}}$ \\
\hline$W R$ & $23.0 \pm 0.1^{\mathrm{a}}$ & $200 \pm 0.1^{\mathrm{d}}$ & $45.2 \pm 0.1^{\mathrm{a}}$ & $40.4 \pm 0.1^{\mathrm{a}}$ & $20.0^{\mathrm{b}}$ & $0.62 \pm 0.1^{b}$ \\
\hline Shanthi & $15.0 \pm 0.1^{\mathrm{b}}$ & $220 \pm 0.1^{\mathrm{c}}$ & $43.8 \pm 0.1^{\mathrm{b}}$ & $41.0 \pm 0.1^{\mathrm{a}}$ & $30.0^{\mathrm{a}}$ & $0.62 \pm 0.1^{\mathrm{b}}$ \\
\hline$H M$ & $25.0 \pm 0.1^{\mathrm{c}}$ & $160 \pm 0.1^{b}$ & $45.2 \pm 0.1^{\mathrm{a}}$ & $39.4 \pm 0.1^{\mathrm{a}, \mathrm{b}}$ & $30.0^{\mathrm{a}}$ & $0.80 \pm 0.1^{\mathrm{a}}$ \\
\hline CARI 09 & $27.0 \pm 0.1^{\mathrm{c}}$ & $140 \pm 0.1^{\mathrm{e}}$ & $45.7 \pm 0.1^{\mathrm{a}}$ & $41.0 \pm 0.1^{\mathrm{a}}$ & $30.0^{\mathrm{a}}$ & $0.75 \pm 0.1^{\mathrm{c}}$ \\
\hline CARI 273 & $25.0 \pm 0.1^{\mathrm{c}}$ & $160 \pm 0.1^{b}$ & $44.1 \pm 0.1^{\mathrm{a}}$ & $42.2 \pm 0.1^{\mathrm{c}}$ & $20.0^{\mathrm{b}}$ & $0.71 \pm 0.1^{\mathrm{c}}$ \\
\hline CARI 426 & $20.0 \pm 0.1^{\mathrm{a}}$ & $140 \pm 0.1^{\mathrm{e}}$ & $48.0 \pm 0.1^{\mathrm{c}}$ & $40.2 \pm 0.1^{\mathrm{a}}$ & $16.0^{\mathrm{c}}$ & $0.67 \pm 0.1^{\mathrm{c}}$ \\
\hline Ranabima & $23.0 \pm 0.1^{\mathrm{a}}$ & $200 \pm 0.1^{\mathrm{d}}$ & $42.9 \pm 0.1^{b}$ & $38.1 \pm 0.1^{\mathrm{b}}$ & $18.0^{c}$ & $0.67 \pm 0.1^{\mathrm{c}}$ \\
\hline$G W$ & $25.0 \pm 0.1^{\mathrm{c}}$ & $220 \pm 0.1^{c}$ & $42.0 \pm 0.1^{\mathrm{b}}$ & $40.0 \pm 0.1^{\mathrm{a}}$ & $30.0^{\mathrm{a}}$ & $0.80 \pm 0.1^{\mathrm{a}}$ \\
\hline Chithra & $20.0 \pm 0.1^{\mathrm{a}}$ & $220 \pm 0.1^{\mathrm{c}}$ & $42.9 \pm 0.1^{\mathrm{b}}$ & $41.0 \pm 0.1^{\mathrm{a}}$ & $30.0^{\mathrm{a}}$ & $0.67 \pm 0.1^{\mathrm{c}}$ \\
\hline$M P$ & $20.0 \pm 0.1^{\mathrm{a}}$ & $120 \pm 0.1^{\mathrm{a}}$ & $44.1 \pm 0.1^{\mathrm{a}}$ & $40.2 \pm 0.1^{\mathrm{a}}$ & $20.0^{\mathrm{b}}$ & $0.95 \pm 0.1^{\mathrm{d}}$ \\
\hline
\end{tabular}

Data presented as mean $\pm \mathrm{SD} ; \mathrm{n}=5$; In each column, different superscripts indicate significant varietal differences at $\mathrm{P} \leq 0.05$.

\section{DISCUSSION}

This study reported the nutrient composition and functional properties of 12 Sri Lankan sweet potato varieties. Considering proximate composition of ash, previous Sri Lankan findings on ash content of some sweet potato varieties were lower (Senanayake et al., 2013a) than the present study. Ash contents of the present study were more or less similar to the sweet potato varieties grown in other countries (BahadoSingh et al., 2011; Ellong et al., 2014) while higher than the varieties in Rwanda (Rose and Vasanthakaalam, 2011). The variations could be due to the differences in minerals in soil, maturity and the extent of peeling.

In the present study, as the crude protein content of flour was less than 5\% except in $M P$ variety, these tubers are not good sources of protein similar to many other tubers (Senavirathna et al., 2014). The high protein in MP may be due to presence of nonprotein nitrogen compounds (Ekanayake and Collins, 2004), which are accounted for when protein is measured by Kjeldhal method. Protein content varied when compared with reported data where some were lower (Rose and Vasanthakaalam, 2011; Senanayake et al., 2013(a)) or higher (Bahado-Singh et al., 2011; Ellong et al., 2014) or similar (Waramboi et al., 2011). These variations may be due to the varietal differences.

The fat contents of the present study were higher than the fat contents in reported studies, which ranged between $0.02-1 \%$ on dry weight basis (Bahado-Singh et al., 2011; Ellong et al., 2014). The variations may be due to the fat extraction method used in the present study which may have influenced most fat soluble substances to be extracted in to the solvent.

There was a difference between the carbohydrate contents reported in this study using enzymatic method and phenol sulfuric method. It is due to the total sugars measured in phenol sulfuric assay against enzymatic method measuring only glucose (from starch, maltose and free glucose) present in digestible and resistant starch in sweet potato flour. The phenol sulfuric assay has been used for measuring neutral sugars in oligosaccharides, proteoglycans, glycoproteins, and glycolipids as well (Masuko et al., 2005). Thus in the present study the higher value reported may 
be due to sugars released following degradation of oligosaccharides and sucrose present in sweet potatoes.

Compared with the reported Sri Lankan varieties, Jamaican (Bahado-Singh et al., 2011) varieties have comparatively higher carbohydrates contents except for $M P$ variety. Ellong et al. (2014) also reported comparatively higher carbohydrate contents than present Sri Lankan values. However, both the latter studies have determined carbohydrate content by difference and carbohydrates represent total fiber, starch and sugars in the study of Ellong et al. (2014). Similar carbohydrate content to present study was reported by acid hydrolysis method (Senanayake et al., 2013a).

Compared with the reported total dietary fiber content of prsent study, Jamaican (Bahado-Singh et al., 2011) varieties had similar values to the present results while other reported values (Rose and Vasanthakaalam, 2011; Senanayake et al., 2013a) were lower. The variations may be due to the difference in the maturity of tubers or the roughage.

Dietary fiber content of other tuber crops like cassava, potatoes and yams (Dioscorea sp.) were comparatively lower than sweet potatoes reported in the pesent study (on dry weight basis) (Famurewa et al., 2013; Chandrasekara and Kumar, 2016). Hence sweet potaoes can be considerd as a source of prebiotics which promote the action of probiotics in human gastrointestinal tract, as it contain consiberable proportions of insoluble and soluble dietary fibers (Park and Floch, 2007).

Functional properties of a flour is important in determining the suitability and uses in incorporation into food industry as functional ingredients, evaluate and to predict how proteins, fat, fiber and carbohydrates may behave in specific systems.

Swelling power is a measure of hydration capacity, occurring due to swollen starch granules and retained water which is often linked with the eating quality of the foods (Falade and Okafor, 2015). Swelling capacity of flours depend on the size of particles, types of variety and types of processing methods or unit operations (Chandra et al., 2015).

Present study resulted comparatively higher swelling capacities (SC) for sweet potato flour than for sweet potato starch (Senanayake et al., 2013b), wheat, rice and green gram flour (Chandra, 2013) which could be due to varietal differences and the high polysaccharide content in these tubers (Butt and Batool, 2010). Swelling capacity of sweet potatoes indicates that the flour could be incorporated in to produce bakery products.

Oil absorption capacity is the measure of emulsifying capacity and the amount of oil that can be picked up by a sample. Oil absorption capacity above $120 \%$ in the present study indicating these flour types have good fat absorption which can be useful in food industry for the structural interaction in food such as flavor retention, improvement of palatability and extension of shelf life in bakery products where fat absorption is required (Aremu et al., 2007). Oil absorption capacity of wheat flour is reported as $146 \%$ (Chandra, 2013) which is less than values obtained with most of sweet potato raw flour. Thus this flour has the ability to be incorporated in place of wheat flour to some extent in the bakery industry to improve above mentioned qualities.

Comparatively higher emulsion activity and stability in sweet potato flour in the present study, indicate the suitability of sweet potato flour in incorporating in to bakery products (Eduardo et al., 2014). The emulsion activity $(>40 \%)$ and stability (>38) of the present study were comparable with the wheat flour which contain more proteins compared to sweet potato (Chandra, 2013).

The foam capacity and foam stability of all the sweet potato flour were insignificant in this study. Proteins cause a lowering of the surface tension at the water air interface, which forms a continuous cohesive film around the air bubbles in the foam (Kaushal et 
al., 2012). As these properties are based on the protein content of flour, sweet potato will not be able to produce stable foam. However, in composite flour mixture with the incorporation of legume flour rich in protein will help to increase the foam capacity to some extent.

The least gelation concentration is defined as the lowest protein concentration at which gel remained in the inverted tube and is influenced by physical competition for water between protein gelation and starch gelatinization of particular flour type (Kaushal et al., 2012). When the least gelation concentration reduces, it leads to improve the swelling ability of the flour (Kaushal et al., 2012). Rice flour forms a gel at a lower concentration $(6 \mathrm{~g} / 100 \mathrm{~mL})$ compared sweet potato (Chandra, 2013). In comparison to rice, sweet potatoes contain low protein content thus higher amount of flour is required for gel formation.

Also bulk density is a measure of mass of solid samples, which is important in the food industry; bulk density depends on the particle size and initial moisture content of flours. Flours with high bulking densities are reported as suitable to be used as thickener in food products and for use in food preparation which helps to reduce paste thickness which is essential in convalescent and child feeding (Chandra et al., 2015). Flours with high bulk densities; above $>0.7 \mathrm{~g} / \mathrm{mL}$ can be used as thickeners in food industry (Akubor and Badifu, 2004). Thus flour of Ama, Dhawala, WW, HM, CARI 09, CARI 273, GW and MP may be suitable for use as thickening agents.

As there was a strong positive correlation between total carbohydrates with bulking density, sweet potato varieties such as $M P$, Ama, Dhawala, $H M$ and $G W$ with comparatively higher carbohydrate contents could be good thickening agents in food industry. Considering the observed correlations of Bulking density with the crude protein content, IDF and the crude fat content, $M P$ would be a better option as a thickening agent which may be suitable for formulation of baby foods with its unique appealing purple colour and antioxidants. As carbohydrate contents showed a negative correlation with oil absorption capacity, sweet potato varieties such as Chithra, Shanthi, CARI 273 and Ranabima may act as better flour options for flavor retention and texture in food industry with their comparatively low carbohydrate contents. As swelling capacity showed a positive correlation with SDF, sweet potato varieties like $G W, H M$ and $C A R I 273$, may be suitable for the incorporation in to foods such as extruded food products which require more water retention (Butt and Batool, 2010) in relation to improve food quality.

\section{Conclusion}

The studied sweet potato tuber flours, are a good source of energy with provision of $8.5 \%$ of total dietary fiber with the highest proportion from insoluble dietary fiber. Ash, crude fat and crude protein contents of less than $7 \%$ with total carbohydrate content between of $49-77 \%$ were found in sweet potato flour. Functional properties resulted high swelling capacity with oil absorption capacities above $100 \%$. According to the functional properties most of the above flour could be used to substitute wheat or rice flour to a certain extent in food industry.

\section{COMPETING INTERESTS}

The authors declare that they have no competing interests.

\section{AUTHORS' CONTRIBUTIONS}

GRNNW conducted the laboratory experiments, collected and analysed the data, drafted the preliminary manuscript and SE designed the study, directed experimental work and data analyses, corrected and improved the scientific quality of the manuscript.

\section{ACKNOWLEDGEMENTS}

The authors acknowledge the University of Sri Jayewardenepura [grant number ASP/01/RE/MED/2015/48] for the 
financial support, the research officers \& staff of Plant Genetic Resource Center, Gannoruwa, Agricultural Research Center, Makandura, Sri Lanka and excellent technical support by Mrs. K.G. Amarathunga, Department of Biochemistry, Faculty of Medical Sciences, University of Sri Jayewardenepura, Nugegoda, Sri Lanka.

\section{REFERENCES}

Akubor PI, Badifu GIO. 2004. Chemical composition, functional properties and baking potential of African breadfruit kernel and wheat flour blends. International Journal of Food Science and Technology, 39(2): 223-229. DOI: https://doi.org/10.1046/j.09505423.2003.00768.x.

AOAC. 1984. Official Methods of Analysis of the AOAC (ed). AOA International : Washington DC.

AOAC. 2000. Official Methods of Analysis of Association of Official Analytical Chemists (Ed). AOA International : Washington DC.

Aremu MO, Olaofe O, Akintayo ET. 2007. Functional properties of some nigerian varieties of legume seed flours and flour concentration effect on foaming and gelation properties. Journal of Food Technology, 5(2): 109-115.

Bahado-Singh PS, Riley CK, Wheatley AO, Lowe HIC. 2011. Relationship between processing method and the glycemic indices of ten sweet potato (Ipomoea batatas) cultivars commonly consumed in Jamaica. Journal of Nutrition and Metabolism, $\quad$ 6. https://doi.org/10.1155/2011/584832

Butt MS, Batool R. 2010. Nutritional and functional properties of some promising legumes protein isolates. Pakistan Journal of Nutrition, 9(4): 373-379. DOI:

https://doi.org/10.3923/pjn.2010.373.379

Chandra S. 2013. Assessment of functional properties of different flours. African Journal of Agricultural Research, 8(38):
4849-4852.

DOI: 10.5897/AJAR2013.6905

Chandra S, Singh S, Kumari D. 2015. Evaluation of functional properties of composite flours and sensorial attributes of composite flour biscuits. Journal of Food Science and Technology, 52(6): 3681-3688. DOI: https://doi.org/10.1007/s13197-0141427-2

Chandrasekara A, Kumar TJ. 2016. Roots and tuber crops as functional foods: A review on phytochemical constituents and their potential health benefits. International Journal of Food Science, 2016: 1-15. DOI:

https://doi.org/10.1155/2016/3631647

Croon L, Guchs G. 1980. Fatthaltsbestamning I mjol och mjolprodketer (Crude fat analysis of different flours and flour products). Var Foda., 32: 425-427.

Djinet AI, Nana R, Tamini Z, Badiel B. 2014. Mise en évidence des valeurs nutritionnelles de dix (10) variétés de patate douce [Ipomea batatas (L.) Lam.] $\mathrm{du}$ Burkina Faso (Highlighting nutritional value of ten (10) varieties of sweet potato (Ipomoea batatas (L.) Lam.) of Burkina Faso). International Journal of Biological and Chemical Sciences, 8(5): 2062-2070. DOI: http://dx.doi.org/10.4314/ijbcs.v8i5.12

Doussoh AM, Dangou JS, Houedjissin SS, Assogba AK, Ahanhanzo C. 2016. Analyse des connaissances endogènes et des déterminants de la production de la patate douce [Ipomoea batatas (L.)], une culture à haute valeur socioculturelle et économique au Bénin (Analysis of endogenous knowledge and determinants of sweet potato production [Ipomoea batatas (L.)], a high socio-cultural and economic value culture in Benin). International Journal of Biological and Chemical Sciences, 10(6): 2596-2616. DOI: http://dx.doi.org/10.4314/ijbcs.v10i6.16 Dubois M, Gilles KA, Hamilton JK, Rebers 
PA, Smith F. 1956. Colorimetric method for determination of sugars and related substances. Analytical Chemistry, 28: 350-356. DOI: https://doi.org/10.1021/ac60111a017

Eduardo M, Svanberg U, Ahrne L. 2014. Effect of hydrocolloids and emulsifiers on baking quality of composite CassavaMaize-Wheat breads. International Journal of Food Science, 2014: 479630. DOI: http://dx.doi.org/10.1155/2014/479630

Ekanayake IJ, Collins W. 2004. Effect of irrigation on sweet potato root carbohydrates and nitrogenous compounds. Food, Agriculture \& Environment, 2(1): 243-248. DOI: https://doi.org/10.1234/4.2004.130

Ellong EN, Billard C, Adenet S. 2014. Comparison of physicochemical, organoleptic and nutritional abilities of eight sweet Potato (Ipomoea batatas) varieties. Food and Nutrition Sciences, 5(2): 196-211. DOI: https://doi.org/ 10.4236/fns.2014.52025

Falade KO, Okafor CA. 2015. Physical, functional, and pasting properties of flours from corms of two Cocoyam (Colocasia esculenta and Xanthosoma sagittifolium) cultivars. Journal of Food Science and Technology, 52(6): 34403448.

DOI:

https://doi.org/10.1007/s13197-0141368-9

Famurewa JAV, Oluwamukomi MO, Alaba Jo. 2013. Effect of different drying methods on the physicochemical characteristics of cassava flour ("pupuru"). International Journal of Biological and Chemical Sciences, 7(2): 832-839.

DOI: http://dx.doi.org/10.4314/ijbcs.v7i2.38

Food and Agriculture Organization (FAO). 2016. Food and agricultural data, Sweet potatoes, Crops (production). FAO. http://www.fao.org/faostat/en/\#search/S weet potatoes

Jones D, Chinnaswamy R, Tan Y, Hanna M.
2000. Physiochemical properties of ready-to-eat breakfast cereals. Cereal Foods World, 45(164): 168.

Kaushal P, Kumar V, Sharma HK. 2012. Comparative study of physicochemical, functional, antinutritional and pasting properties of taro (Colocasia esculenta), rice (Oryza sativa) flour, pigeonpea (Cajanus cajan) flour and their blends. LWT - Food Science and Technology, 48(1): 59-68. DOI: https://doi.org/10.1016/j.lwt.2012.02.028

Masuko T, Minami A, Iwasaki N, Majima T, Nishimura SI, Lee YC. 2005. Carbohydrate analysis by a phenolsulfuric acid method in microplate format. Analytical Biochemistry, 339(1): 69-72.

DOI: https://doi.org/10.1016/j.ab.2004.12.001

Mussoline WA, Wilkie AC. 2017. Feed and fuel: the dual-purpose advantage of an industrial sweet potato. Journal of the Science of Food and Agriculture, 97(5): 1567-1575.

DOI: https://doi.org/10.1002/jsfa.7902

Okaka JC, Potter NN. 1977. Functional and storage properties of Cowpea Powder-Wheat flour blends in bread making. Journal of Food Science, 42(3): 828-833.

DOI: https://doi.org/10.1111/j.13652621.1977.tb12614.x

Oluwalana IB, Malomo SA, Ogbodogbo EO. 2012. Quality assessment of flour and bread from sweet potato wheat composite flour blends. International Journal of Biological and Chemical Sciences, 6(1): 65-76. DOI: http://dx.doi.org/10.4314/ijbcs.v6i1.6

Park J, Floch MH. 2007. Prebiotics, probiotics, and dietary fiber in gastrointestinal disease. Gastroenterology Clinics of North America, 36(1): 47-63. DOI: https://doi.org/10.1016/j.gtc.2007.03.001

Rose I, Vasanthakaalam H. 2011. Comparison of the nutrient composition of four sweet potato varieties cultivated in Rwanda. 
American Journal of Food and Nutrition, 1(1): $\quad 34-38 . \quad$ DOI: https://doi.org/10.5251/ajfn.2011.1.1.34. 38

Senanayake SA, Ranaweera KKDS, Gunaratne A, Bamunuarachchi A. 2013a. Comparative analysis of nutritional quality of five different cultivars of sweet potatoes (Ipomea batatas (L) Lam) in Sri Lanka. Food Science and Nutrition, 1(4): 284-291. DOI: https://doi.org/10.1002/fsn3.38

Senanayake S, Gunaratne A, Ranaweera KKDS, Bamunuarachchi A. 2013b. Physico - chemical properties of five cultivars of sweet potato (Ipomea batatas Lam $(L)$ ) root tubers grown in Sri Lanka. Tropical Agriculture, 90(2): 87-96.

Senavirathna RMISK, Sagarika E, Radcliff JE, Jayantha W. 2014. Proximate composition, glycemic indices, and some factors affecting glycemic indices of underutilized tubers. Starch/Starke, 66(11-12): 1041-1048. DOI: $10.1002 /$ star.201400059

Shekhar S, Mishra D, Buragohain AK, Chakraborty S, Chakraborty N. 2015. Comparative analysis of phytochemicals and nutrient availability in two contrasting cultivars of sweet potato (Ipomoea batatas L.). Food Chemistry, 173: 957-965. DOI: https://doi.org/10.1016/j.foodchem.2014. 09.172

Sosulski FW, Garatt MO, Slinkard AE. 1976. Functional properties of ten legume flours. International Journal of Food Science and Technology, 9: 66-69. DOI: 10.12691/ajfst-2-4-4

Tang Y, Cai W, Xu B. 2015. Profiles of phenolics, carotenoids and antioxidative capacities of thermal processed white, yellow, orange and purple sweet potatoes grown in Guilin, China. Food Science and Human Wellness, 4(3): 123-132. DOI: https://doi.org/10.1016/j.fshw.2015.07.0 03

Wang A, Li R, Ren L, Gao X, Zhang Y, Ma Z, Ma D, Luo Y. 2018. A comparative metabolomics study of flavonoids in sweet potato with different flesh colors (Ipomoea batatas (L.) Lam). Food Chemistry, 260: 124-134. DOI: https://doi.org/10.1016/j.foodchem.2018. 03.125

Waramboi JG, Dennien S, Gidley MJ, Sopade PA. 2011. Characterisation of sweetpotato from Papua New Guinea and Australia: physicochemical, pasting and gelatinisation properties. Food Chemistry, 126(4): 1759-1770. DOI: https://doi.org/10.1016/j.foodchem.2010. 12.077

Yasumatsu K, Sawada K, Moritaka S, Misaki M, Toda J, Wada T, Ishii K. 1972. Whipping and emulsifying properties of soybean Products. Agricultural and Biological Chemistry, 36(5): 719-727. DOI: https://doi.org/10.1080/00021369.1972.1 0860321. 